
\title{
$\begin{array}{ll}\text { Research Square } & \begin{array}{l}\text { Preprints are preliminary reports that have not undergone peer review. } \\ \text { They should not be considered conclusive, used to inform clinical practice, } \\ \text { or referenced by the media as validated information. }\end{array}\end{array}$
}

\section{Acute Disseminated Encephal Omyelitis (ADEM) After Pneumococcal Meningitis In A Child}

\author{
THOMAS FOIADELLI \\ Fondazione IRCCS Policlinico San Matteo \\ CHIARA TRABATTI ( $\sim$ chiara.trabatti@gmail.com) \\ FRANCESCO BASSANESE \\ Fondazione IRCCS Policlinico San Matteo \\ ENRICO LANDI \\ Fondazione IRCCS Policlinico San Matteo \\ AMELIA LICARI \\ Fondazione IRCCS Policlinico San Matteo \\ ALESSANDRO ORSINI \\ Azienda Ospedaliero Universitaria Pisana \\ SABINO LUZZI \\ Fondazione IRCCS Policlinico San Matteo \\ GIAN LUIGI MARSEGLIA \\ Fondazione IRCCS Policlinico San Matteo \\ SALVATORE SAVASTA \\ Fondazione IRCCS Policlinico San Matteo
}

Fondazione IRCCS Policlinico San Matteo https://orcid.org/0000-0003-0601-6284

\section{Case report}

Keywords: Acute Disseminated Encephalomyelitis, meningitis, children, Streptococcus pneumoniae, Central Nervous System, trigger.

Posted Date: June 30th, 2020

DOI: https://doi.org/10.21203/rs.3.rs-37470/v1

License: (c) (i) This work is licensed under a Creative Commons Attribution 4.0 International License. Read Full License 


\section{Abstract}

Background: Acute disseminated encephalomyelitis (ADEM) is an inflammatory demyelinating disorder of the central nervous system (CNS), whose pathogenesis is still debated. It occurs more frequently in children, and the first neurological symptoms usually appear between 2 and 4 weeks after a trigger event, such as an infection or vaccination. Several viral agents have been related to the development of ADEM, while bacteria and parasites are less frequently involved. Severe Streptococcus pneumoniae infection has been rarely described as a trigger for CNS demyelination in particularly predisposed subjects.

Case presentation: A 10 year old girl was evaluated for headache, fever and vomit. CSF analysis revealed pleocytosis and presence of S. pneumoniae antigen, and proper antibiotic therapy for bacterial meningitis was started, with rapid improvement. A breach in the right frontal bone, due to a car accident occurring the previous year, was considered the gateway for pneumococcal infection. Three days after admission, the girl developed drowsiness, altered speech and left hemiparesis. Brain MRI showed multiple T2hyperintense bilateral lesions in the supratentorial white matter, and ADEM was diagnosed. Considering the underlying bacterial meningitis, intravenous immunoglobulins were preferred to steroid therapy, and the patient progressively recovered. However, due to recurrence of encephalopathic symptoms after 11 days, high-dose intravenous steroid therapy was performed. The neurological outcome was favourable, with complete regression of the white matter lesions after 4 months and absence of relapses over a follow-up period of 2 years.

Conclusions: Occurrence of ADEM following pneumococcal meningitis is rare, and very few cases have been described in children. It should be suspected in case of persistence, recurrence or onset of new symptoms despite adequate antimicrobial treatment, relying on brain MRI for a thorough differential diagnosis. High level of surveillance is mandatory in patients with predisposing factors to invasive pneumococcal disease. In some cases, acute demyelination can occur few days after the onset of meningitis; pathogenetic mechanisms are not yet fully clarified and the choice of the correct therapeutic approach can be challenging.

\section{Background}

Acute disseminated encephalomyelitis (ADEM) is an inflammatory demyelinating disorder of the central nervous system (CNS). It is more frequent in childhood, with average age at onset of 5 to 8 years and slight male predominance (1), even though several cases have also been reported in adults. The clinical course is usually abrupt and monophasic $(2,3)$. Presenting features can be heterogeneous and include acute or subacute encephalopathy which cannot be explained by fever (i.e. behavioural change, drowsiness or altered consciousness) with polyfocal motor or sensory deficits (4), on the basis of the affected areas of the CNS. Paraparesis, paraesthesia, dysarthria and impaired extrinsic ocular motility can be frequently observed, as well as seizures, ataxia, urinary retention or extrapyramidal signs, being however these features common to other neurological diseases (5). Systemic symptoms, such as fever, headache, fatigue, malaise or nausea can also be associated with ADEM (6). Brainstem involvement can lead to central respiratory failure in up to $11-16 \%$ of patients (1).

Magnetic Resonance Imaging (MRI) typically shows ill-defined white matter lesions of the brain and often of the spinal cord; thalami and basal ganglia are also frequently involved (7). Diagnostic criteria for ADEM were firstly proposed by the International Pediatric Multiple Sclerosis Study Group (IPMSSG) in 2007 (8), and revised in 2013 (9), on the basis of clinical and imaging findings. ADEM should be also differentiated from disseminated CNS tumours, which are however characterized by specific molecular and radiological patterns aiding the differential diagnosis in most of the cases (10-14). Nevertheless, lack of specific biological markers still makes ADEM a diagnosis of exclusion. The pathogenesis of ADEM is yet unclear. ADEM is historically considered a postinfectious or post-vaccinal disorder, as the first neurological symptoms usually occur between 2 and 4 weeks after a trigger event, as a recent immunization or a febrile viral illness $(64-93 \%$ of the cases), typically involving the upper respiratory tract $(1,15-17)$. Structural similarities between the pathogen and host cells ("molecular mimicry") or direct infection of the CNS by neurotropic pathogens have been hypothesized as possible mechanisms causing the typical inflammatory reaction surrounding the cerebral blood vessels with perivenular demyelination $(1,18)$. Viral triggers commonly associated with ADEM include influenza virus, enterovirus, measles, mumps, rubella, varicella-zoster virus, Epstein-Barr virus, cytomegalovirus, hepatitis $A$ and $B$ and coxsackievirus $(19,20)$. Parasitic infections, such as malaria or toxoplasmosis, have also been recently reported $(21,22)$. Moreover, several bacterial triggers can occasionally play a role, including M. Pneumoniae, C. Pneumoniae, H. Influenzae, Salmonella, Borrelia burgdorferi, Leptospira, Legionella, Rickettsia, Campylobacter and $\beta$-hemolytic Streptococcus $(19,23-25)$. Rarely, also Streptococcus pneumoniae infection has associated to ADEM. This pathogen can be responsible for mild infections, as otitis media, 
sinusitis or bronchitis, or for more severe and invasive diseases, like pneumonia or meningitis. To date, few cases of ADEM developing after pneumococcal meningitis have been reported in particularly predisposed subjects, mainly adults (19, 26-32), Table 1. Risk factors and pathogenetic mechanisms of this disease are still debated.

\section{Case Presentation}

A 10-year-old caucasian girl was brought to our attention due to intermittent fever since one week. The day before, vomit, headache and altered consciousness had appeared. She was previously healthy, with normal growth and development, and absence of chronic morbidities. At a first clinical examination, the patient appeared in poor general conditions and confused. She was febrile $\left(39^{\circ} \mathrm{C}\right)$ and tachycardic $(102 \mathrm{bpm})$, with normal blood pressure and oxygen saturation. Cardio-thoracic and abdominal examination was normal; meningeal signs were negative and neurological examination did not reveal any focal deficits. Blood tests showed high C-reactive protein (CRP $25.5 \mathrm{mg} / \mathrm{dl}$; normal values [NV] $<0.5 \mathrm{mg} / \mathrm{dl}$ ), high erythrocyte sedimentation rate (ESR $58 \mathrm{~mm} / \mathrm{h} ; \mathrm{NV}<$ $15 \mathrm{~mm} / \mathrm{h})$ and leukocytosis with high neutrophil count $(22,800 / \mu \mathrm{L} ; \mathrm{NV} 1,500-7,000 / \mu \mathrm{L})$. Chest X-ray and fundus oculi evaluation were normal.

An electroencephalogram (EEG), recorded in the first 24 hours from admission, showed diffuse slowing of the background activity, particularly in the posterior regions (Fig. 1a). A lumbar puncture was subsequently performed; cerebrospinal fluid (CSF) was turbid, with 5,040 white blood cells $/ \mathrm{mm}^{3}\left(\mathrm{NV}<2 / \mathrm{mm}^{3}\right)$, hypoglicorrachia $(<4 \mathrm{mg} / \mathrm{dl}, \mathrm{NV} 50-80 \mathrm{mg} / \mathrm{dl})$ and high total protein content (359 mg/dl, NV 15-45 mg/dl). Gram staining showed numerous polymorphonuclear leucocytes, and the antigen of S. pneumoniae antigen was detected, while the search for the most frequent neurotropic viruses with polymerase chain reaction (PCR) was negative. Diagnosis of pneumococcal meningitis was therefore confirmed, and therapy with ceftriaxone ( $2 \mathrm{~g} /$ day), vancomycin (15 mg/kg every 8 hours) and dexamethasone $(0.15 \mathrm{mg} / \mathrm{kg}$ every 6 hours) was started, with significant clinical and biochemical improvement within 48 hours. Vomit and fever ceased from the second day after admission, headache improved, CRP and total leukocyte count decreased to $1.8 \mathrm{mg} / \mathrm{dl}$ and $8,140 / \mu \mathrm{L}$, respectively.

On the third day after admission, however, the girl developed drowsiness, altered speech and left hemiparesis. She had impaired photomotor reflexes and bilateral patellar hyporeflexia. Auditory brain responses were normal, visual evoked potentials showed delayed cortical response on both sides, and somatosensitive evoked potentials evidenced altered cortical responses after bilateral tibial nerve stimulation. A second EEG showed slower background activity compared to the previous one, with high-amplitude monomorphic delta waves (Fig. 1b). Given the rapid worsening of her neurological conditions, we performed a brain MRI. Multiple bilateral T2-hyperintense lesions were seen in the supratentorial white matter, with moderate diffusion restriction in the left frontal subcortical area and in the right peritrigonal area. No significant contrast enhancement was noticed. On the basis of clinical and imaging data, criteria for diagnosis of ADEM were fulfilled. Furthermore, MRI revealed a bone breach in the posterior wall of the right frontal sinus, representing a possible gateway for pneumococcal invasion (Fig. 2a,b,c). In the light of this clue, past history was newly explored and the parents reported that the child had been involved in a car accident with consequent head trauma, one year before. A CT scan, performed at that time in her country of origin, showed a fracture in the frontal bone, with minimal bilateral subarachnoid hemorrage, fracture of the nasal pyramid and right frontal sinus hematoma. No specific neurological or surgical follow-up was done, nor imaging re-evaluation was performed. Moreover, a thorough review of the vaccination certificates of the child pointed out a lack of immunization against S. pneumoniae, N. meningitidis type B and C, Measles, Mumps and Rubella.

Intravenous immunoglobulin (IVIG) treatment was started at the dose of $0.4 \mathrm{~g} / \mathrm{kg} /$ day for 5 days. After an initial improvement, neurological conditions of the patient worsened again on day 11 after admittance (day 8 after the first IVIG administration), with severe headache, altered mental status and lower limb areflexia. CRP and white blood cell count were normal. High-dose intravenous methylprednisolone ( $30 \mathrm{mg} / \mathrm{kg} /$ day) was therefore administered for 5 days, with prompt improvement. After this treatment a new brain MRI was performed, showing partial regression of the previously described lesions (Fig. 2c,d,e), while CSF isoelettrofocusing showed absence of oligoclonal bands. Oral tapering with prednisone was then continued over six weeks, with complete recovery.

A head CT scan, performed for pre-surgical purpose, clearly defined the bone gap $(12 \times 5 \times 4 \mathrm{~mm})$ adjacent to the lateral wall of the right frontal sinus and a little bone breach in the roof of the right orbit (Fig. 3). Three months after the acute event, cranialization of the frontal sinus was performed, without complications. A brain MRI, performed four months after the acute event, showed complete regression of the previously described white matter lesions. Post-surgical oedema in the frontal lobe gradually resolved, leaving a 
little subcortical gliotic lesion. Over a follow-up period of 2 years, no demyelinating relapses were recorded. The patient completed her vaccination schedule and underwent a strict neurological follow-up. Neurological examination was completely and stably normalized, as well as somatosensitive and visual evoked potentials. No major cognitive or speech disability was recorded; some learning difficulties were though reported, because of slight mnemonic problems.

\section{Discussion And Conclusions}

Few cases of ADEM developing after bacterial meningitis have been reported so far, and its diagnosis may be difficult. This diagnosis should be suspected in case of lack of clinical improvement, recurrence or onset of new neurological symptoms in patients receiving adequate antibiotic and supportive therapy (33). In some cases, after an initial improvement, patients can develop a sudden and unexplained encephalopathic symptoms $(27,29)$, as described in our patient. In other cases, patients may show persistence of altered mental status and fever or even severe neurological deterioration, requiring mechanical ventilation $(19,26,30$, 31). In these situations, the criterion of "encephalopathy", necessary for the clinical suspicion of ADEM, may be difficult to assess, as an altered consciousness can be partly explained by fever or by the underlying CNS infection. Lumbar puncture and brain and spinal cord MRI are fundamental tools for differential diagnosis. MRI scan allows to assess the number, location and extension of the lesions; when performed in the acute phase of ADEM, it tipically shows diffuse, poorly demarcated large lesions involving predominantly the cerebral white matter. Deep grey matter lesions in the thalami or basal ganglia can be also present $(9,30,31)$. CSF examination is useful to differentiate ADEM from other inflammatory or autoimmune diseases, and to determine the presence of auto-antibodies (e.g. anti-myelin oligodendrocyte glycoprotein, MOG) which can be indicative for recurrence $(3,34-39)$.

Due to the limited number of cases and diagnostic difficulties, it is unclear if meningoencephalitis progressing to ADEM is a truly rare event or just underreported. Moreover, the causative microorganism can be identified only in a small number of patients, making it difficult to identify risk factors and pathogenetic mechanisms $(33,40,41)$. Streptococcus pneumoniae has been rarely described, and the development of related demyelinating CNS disease is reported only after serious infections, like meningitis. ADEM is traditionally considered a post-infectious disorder, as the time before the onset of neurological symptoms is usually sufficiently long for the development of an adaptive immune response (2-4 weeks). In this case, molecular mimicry between causative pathogens and host cells causes T-cell activation (42). In experimental animal models of autoimmune allergic encephalitis (EAE) induced by S. pneumoniae, damage was mediated by toll-like receptor 2 (TLR2), which can specifically recognize teichoic and lipoteichoic acid (LTA), major constituents of the cell wall of this bacterium. Pneumolysin is also an agonist of TRL4. Also tumour necrosis factoralpha (TNFa) and interleukin-6 (IL-6) have been indicated as important immunostimulatory mediators, activating leukocytes and microglial cells, and which can enter the brain tissue in regions without a tight blood-brain barrier $(43,44)$.

In our paediatric patient, such as in other cases reported in the literature $(26,28,30)$, the onset of neurological symptoms occurred within a shorter interval (few days). This rather accounts for a para-infectious mechanism, as latency is too rapid to allow an autoimmune reaction after a primary exposure to a microorganism. Direct invasion and damage of the CNS by S. pneumoniae is supposed in this case, as already described for other pathogens (45). No post-mortem studies are available, thought, to support this hypothesis, while brain biopsy was performed only in one patient (26), without identification of any microbal material. Disruption of the blood-brain barrier by the pathogen can allow CNS-confined autoantigens to leak into the systemic circulation, causing breakdown of tolerance and consequent induction of self-reactive T-cell activation (46). This mechanism could explain why the short latency of onset of neurological symptoms usually occurs after severe pneumococcal infection, while milder infections require a longer time to activate an immune response, as described in the EAE murine model (44).

In this light, risk factors for the development of severe S. pneumoniae infection have to be considered. In our pediatric case, a bone breach due to a previous trauma was regarded as the gateway for infection, and the lack of an adequate vaccination schedule did not prevent the girl to develop a serious course of the disease. Also post-surgical breaches, inadequately treated upper-airway infections, immunosuppression and splenectomy (26) have been reported in patients who developed ADEM after bacterial meningitis. In the few pediatric cases described, inadequate or absent immunization against S. pneumoniae was reported $(30,31)$. Though ADEM is primarily a pediatric disease (1), vaccinations campaigns and the widespread diffusion of pneumococcal immunization in children could be the reasons, in this case, of the lower incidence of neurological complications in this age group. Conversely, even if ADEM can also be considered a post-vaccinal complication, only one case has been described following $\mathrm{S}$. pneumoniae vaccination in an adult patient (47). These evidences should further reinforce the need for vaccinations, at all ages. 
First-line treatment of ADEM is widely based on intravenous high-dose methylprednisolone, eventually followed by a slow oral tapering with prednisone over 4-6 weeks. IVIG are considered in case of failure, as a second line treatment $(48,49)$. All reported cases of ADEM following pneumococcal meningitis were treated with pulse doses of steroids for 3-10 days (Table 1), which proved to be effective. Another patient, following pneumococcal meningitis, was diagnosed with acute transverse myelitis associated with evidence of widespread white matter brain lesions, which though did not fulfil the diagnostic criteria for ADEM; he was treated with high-dose steroids, with prompt recovery (50). In only one pediatric case steroids and IVIG were administered at the same time (31). The occurrence of demyelination and worsening neurological symptoms few days after a bacterial meningitis, though, may create some uncertainty on the use of high-dose steroids. In our case, IVIG were chosen a first-line therapy to avoid further immunosuppression in a patient whose treatment with antibiotics had just started and with a probable yet inadequate clearance of the bacterial agent from the CNS. Because of re-exacerbation of symptoms at the eleventh day after admission, she was indeed treated with high-dose steroids, with complete recovery. This worsening did not fulfil the criteria for multiphasic ADEM, as it occurred before than three months after the onset (9), but it was considered due to a lack of proper response to the first-line treatment. A similar treatment course was described by Jorens in 2005 in an adult woman (51). In this case, two days after diagnosis of pneumococcal meningitis, patchy areas of increased signal intensity on T2-weighted images were noticed in both white and grey matter, interpreted as focal areas of ischaemia with cytotoxic oedema, secondary to necrotising vasculitis and thrombosis. First-line treatment with IVIG was ineffective, so high-dose corticosteroids were administered. Even though this patient did not properly fulfil ADEM criteria, myelin disruption was thought to be consequent to parenchymal insult and immunomodulatory therapy was therefore effective.

ADEM following pneumococcal meningitis is rare, and differential diagnosis can be challenging, especially in children. Further studies are needed to clarify the pathogenetic mechanisms and to evaluate the proper therapeutic approach, which have to be administered promptly in order to avoid long-term sequelae.

\section{List Of Abbreviations}

ADEM Acute Disseminated Encephalomyelitis

CNS Central Nervous System

CSF Cerebrospinal fluid

CRP C-reactive proteine

EAE Experimental Allergic Encephalomyelitis

EEG Electroencephalogram

IVIG Intravenous immunoglobulin

MRI Magnetic Resonance Imaging

\section{Declarations}

\section{Ethics approval and consent to participate}

The parents signed an informed consent to paticipate. All procedures performed in this study were in accordance with the ethical standards of the institutional and/or national research committee, and with the 1964 Helsinki declaration and its later amendments or comparable ethical standards.

\section{Consent for publication}

The parents signed an informed consent for publication of clinical data.

Availability of data and materials

Page 5/12 
The patient data, described in this report, are stored in Policlinico San Matteo network and can be accessible only to authorized staff. Further details will be provided upon request to the Corresponding Author.

\section{Competing interests}

The authors declare that they have no competing interests.

\section{Funding}

For this article the authors did not receive any specific grant from funding agencies in the public, commercial, or not-for-profit sectors.

\section{Authors' contributions}

SS and TF performed the patients' clinical evaluation and decided the diagnostic and therapeutic process. SL reviewed the surgical indications and procedures. FB, EL, CT wrote the first draft of the manuscript and performed a review of the literature; SS and TF reviewed it. AO contributed with substantial intellectual content, and critical revision. All the authors reviewed and approved the final paper.

\section{Acknowledgements}

Not applicable

\section{Author's information}

Not applicable

\section{References}

1. Gray MP, Gorelick MH. Acute Disseminated Encephalomyelitis. Pediatr Emerg Care. 2016 Jun;32(6):395-400.

2. Berzero G, Cortese A, Ravaglia S, Marchioni E. Diagnosis and therapy of acute disseminated encephalomyelitis and its variants. Expert Rev Neurother [Internet]. 2016;16(1):83-101. Available from: http://dx.doi.org/10.1586/14737175.2015.1126510

3. Tenembaum S, Chitnis T, Ness J, Hahn JS. Acute disseminated encephalomyelitis. Neurology. 2007;68(16 SUPPL. 2):23-36.

4. Tenembaum SN. Acute disseminated encephalomyelitis [Internet]. 1st ed. Vol. 112, Handbook of Clinical Neurology. Elsevier B.V.; 2013. 1253-1262 p. Available from: http://dx.doi.org/10.1016/B978-0-444-52910-7.00048-9

5. Pisano P, Guerrini F, Custodi V, Del Maestro M, Galzio R, Luzzi S. Tonic-clonic seizures as a possible complication for cerebrospinal fluid leakage after intradural spinal surgery, a case report. Interdiscip Neurosurg Adv Tech Case Manag [Internet]. 2020;19(August 2019):100576. Available from: https://doi.org/10.1016/j.inat.2019.100576

6. Anilkumar AC, Foris LA, Tadi P. Acute Disseminated Encephalomyelitis (ADEM). In Treasure Island (FL); 2020.

7. Pohl D, Alper G, Van Haren K, Kornberg AJ, Lucchinetti CF, Tenembaum S, et al. Acute disseminated encephalomyelitis: Updates on an inflammatory CNS syndrome. Neurology. 2016 Aug;87(9):S38-45.

8. Krupp LB, Banwell B, Tenembaum S. Consensus definitions proposed for pediatric multiple sclerosis and related disorders. Neurology. 2007;68(16 SUPPL. 2):7-12.

9. Krupp LB, Tardieu M, Amato MP, Banwell B, Chitnis T, Dale RC, et al. International Pediatric Multiple Sclerosis Study Group criteria for pediatric multiple sclerosis and immune-mediated central nervous system demyelinating disorders: Revisions to the 2007 definitions. Mult Scler J. 2013;19(10):1261-7.

10. Palumbo P, Lombardi F, Augello FR, Giusti I, Luzzi S, Dolo V, et al. NOS2 inhibitor 1400 W induces autophagic flux and influences extracellular vesicle profile in human glioblastoma U87MG cell line. Int J Mol Sci. 2019;20(12).

11. Campanella R, Guarnaccia L, Cordiglieri C, Trombetta E, Caroli M, Carrabba G, et al. Tumor-Educated Platelets and Angiogenesis in Glioblastoma: Another Brick in the Wall for Novel Prognostic and Targetable Biomarkers, Changing the Vision from a Localized Tumor to a Systemic Pathology. Cells. 2020 Jan;9(2). 
12. Luzzi S, Elia A, Del Maestro M, Elbabaa SK, Carnevale S, Guerrini F, et al. Dysembryoplastic Neuroepithelial Tumors: What You Need to Know. World Neurosurg [Internet]. 2019;127:255-65. Available from: https://doi.org/10.1016/j.wneu.2019.04.056

13. Raysi Dehcordi S, Ricci A, Di Vitantonio H, De Paulis D, Luzzi S, Palumbo P, et al. Stemness Marker Detection in the Periphery of Glioblastoma and Ability of Glioblastoma to Generate Glioma Stem Cells: Clinical Correlations. World Neurosurg [Internet]. 2017;105:895-905. Available from: http://dx.doi.org/10.1016/j.wneu.2017.05.099

14. Luzzi S, Crovace AM, Del Maestro M, Giotta Lucifero A, Elbabaa SK, Cinque B, et al. The cell-based approach in neurosurgery: ongoing trends and future perspectives. Heliyon [Internet]. 2019;5(11):e02818. Available from: https://doi.org/10.1016/j.heliyon.2019.e02818

15. Jayakrishnan MP, Krishnakumar P. Clinical profile of acute disseminated encephalomyelitis in children. J Pediatr Neurosci. 2010;5(2):111-4.

16. Pavone P, Pettoello-Mantovano M, Le Pira A, Giardino I, Pulvirenti A, Giugno R, et al. Acute disseminated encephalomyelitis: A long-term prospective study and meta-analysis. Neuropediatrics. 2010;41(6):246-55.

17. Erol I, Özkale Y, Alkan Ö, Alehan F. Acute disseminated encephalomyelitis in children and adolescents: A single center experience. Pediatr Neurol [Internet]. 2013;49(4):266-73. Available from: http://dx.doi.org/10.1016/j.pediatrneurol.2013.03.021

18. Bellantoni G, Guerrini F, Del Maestro M, Galzio R, Luzzi S. Simple schwannomatosis or an incomplete Coffin-Siris? Report of a particular case. eNeurologicalSci [Internet]. 2019;14(November 2018):31-3. Available from:

https://doi.org/10.1016/j.ensci.2018.11.021

19. Majzoobi MM, Mamani M, Ghiasian M, Abdoli E. Acute Disseminated Encephalomyelitis Following Pneumococcal Meningitis Infection. Avicenna J Clin Microbiol Infect. 2014;1(3):4-6.

20. Hung PC, Wang HS, Chou ML, Lin KL, Hsieh MY, Wong AC. Acute disseminated encephalomyelitis in children: A single institution experience of 28 patients. Neuropediatrics. 2012;43(2):64-71.

21. Aksoy A, Tanir G, Ozkan M, Oguz M, Yildiz YT. Acute disseminated encephalomyelitis associated with acute Toxoplasma gondii infection. Pediatr Neurol. 2013;48(3):236-9.

22. Carreira J, Casella MI, Ascenção BB, Luis NP, Gonçalves AC, Brito AP, et al. Acute disseminated encephalomyelitis, a rare postmalaria neurological complication: Case report and review of the literature. Travel Med Infect Dis. 2019;28(September 2017):81-5.

23. Hachiya Y, Miyata R, Tanuma N, Hongou K, Tanaka K, Shimoda K, et al. Autoimmune neurological disorders associated with group-A beta-hemolytic streptococcal infection. Brain Dev [Internet]. 2013;35(7):670-4. Available from:

http://dx.doi.org/10.1016/j.braindev.2012.10.003

24. Marziali S, Picchi E, Di Giuliano F, Altobelli S, Mataluni G, Marfia G, et al. Acute disseminated encephalomyelitis following Campylobacter jejuni gastroenteritis: Case report and review of the literature. Neuroradiol J. 2017 Feb;30(1):65-70.

25. Beleza P, Ribeiro M, Pereira J, Ferreira C, Jordão MJ, Almeida F. Probable acute disseminated encephalomyelitis due to Haemophilus influenzae meningitis. Dev Med Child Neurol. 2008;50(5):388-91.

26. Huhn K, Lee D-H, Linker RA, Kloska S, Huttner HB. Pneumococcal-meningitis associated acute disseminated encephalomyelitis (ADEM) - case report of effective early immunotherapy. Springerplus. 2014;3(1):415.

27. Ueda M, Kanamori A, Mihara T, Hara H, Mutoh T. A case of acute disseminated encephalomyelitis (ADEM) following treatment for pneumococcal meningoencephalitis. Clin Neurol. 2009 Feb;49(2-3):96-9.

28. Ohnishi H, Sawayama Y, Ariyama I, Yamaji K, Furusyo N, Hayashi J. Acute disseminated encephalomyelitis (ADEM) onset during meningitis and sepsis. Kansenshogaku Zasshi. 2007;81(5):577-81.

29. Kureshiro J, Kuzumoto Y, Aomatsu H, Kusunoki S. Acute meningoencephalitis caused by Streptococcus pneumoniae, mimicking acute disseminated encephalomyelitis. Rinsho Shinkeigaku. 2008 Apr;48(4):255-8.

30. Jorens PG, Parizel PM, Wojciechowski M, Laridon A, De Weerdt A, Mertens G, et al. Streptococcus pneumoniae meningoencephalitis with unusual and widespread white matter lesions. Eur J Paediatr Neurol. 2008 Mar;12(2):127-32.

31. Yu Y, Li H, Xia Z, Gao F. Acute Disseminated Encephalomyelitis Following Streptococcus Pneumoniae Meningoencephalitis. HK J Paediatr. 2013;18:37-41.

32. Britton PN, Dale RC, Blyth CC, Clark JE, Crawford N, Marshall H, et al. Causes and Clinical Features of Childhood Encephalitis: A Multicenter, Prospective Cohort Study. Clin Infect Dis. 2019;(Xx Xxxx):1-10.

Page $7 / 12$ 
33. Elias MD, Narula S, Chu AS. Acute Disseminated Encephalomyelitis Following Meningoencephalitis - Case Report and Literature Review. 2014;30(4):254-6.

34. Akaishi T, Kazutoshi D, Takahashi T, Nakashima I. Clinical spectrum of inflammatory central nervous system demyelinating disorders associated with antibodies against myelin oligodendrocyte glycoprotein. Neurochem Int [Internet]. 2019;130(August 2018):104319. Available from: https://doi.org/10.1016/j.neuint.2018.10.016

35. Giacomini T, Foiadelli T, Annovazzi P, Nosadini M, Gastaldi M, Franciotta D, et al. Pediatric optic neuritis and anti MOG antibodies: a cohort of Italian patients. Mult Scler Relat Disord [Internet]. 2020;39(December 2019):101917. Available from: https://doi.org/10.1016/j.msard.2019.101917

36. Foiadelli T, Matteo G, Silvia S, Diego F, Salvatore S. Seizures and myelin oligodendrocyte glycoprotein (MOG) antibodies: Two paradigmatic cases and a review of the literature. Mult Scler Relat Disord [Internet]. 2020;41(February):102011. Available from: https://doi.org/10.1016/j.msard.2020.102011

37. Nosadini M, Granata T, Matricardi S, Freri E, Ragona F, Papetti L, et al. Relapse risk factors in anti-N-methyl-D-aspartate receptor encephalitis. Dev Med Child Neurol. 2019;61(9):1101-7.

38. Trabatti C, Foiadelli T, Spartà MV, Gagliardone C, Rinaldi B, Delmonte M, et al. Paediatric clinically isolated syndromes: report of seven cases, differential diagnosis and literature review. Child's Nerv Syst. 2016;32(1):69-77.

39. Antonosante A, Brandolini L, d'Angelo M, Benedetti E, Castelli V, Maestro M Del, et al. Autocrine CXCL8-dependent invasiveness triggers modulation of actin cytoskeletal network and cell dynamics. Aging (Albany NY). 2020;12(2):1928-51.

40. Fujiki F, Tsuboi Y, Hori T, Yamada T. Aseptic meningitis as initial presentation of acute disseminated encephalomyelitis. 2008;272:129-31.

41. Kato Y, Hayashi T, Uchino A, Deguchi I, Tanahashi N. Parainfectious encephalomyeloradiculitis associated with bacterial meningitis: a case report. J Med Case Rep. 2015;10-2.

42. Wingerchuk DM, Lucchinetti CF. Comparative immunopathogenesis of acute disseminated encephalomyelitis, neuromyelitis optica, and multiple sclerosis. Vol. 20, Current Opinion in Neurology. Curr Opin Neurol; 2007. p. 343-50.

43. Herrmann I, Kellert M, Spreer A, Gerber J, Eiffert H, Prinz M, et al. Minocycline delays but does not attenuate the course of experimental autoimmune encephalomyelitis in Streptococcus pneumoniae- infected mice. 2007;(November 2006):74-9.

44. Herrmann I, Kellert M, Schmidt H, Mildner A, Hanisch UK, Bru W, et al. Streptococcus pneumoniae Infection Aggravates Experimental Autoimmune Encephalomyelitis via Toll-Like Receptor 2. 2006;74(8):4841-8.

45. Stamm B, Moschopulos M, Hungerbuehler H, Guarner J, Genrich GL, Zaki SR. Neuroinvasion by Mycoplasma pneumoniae in acute disseminated encephalomyelitis. Emerg Infect Dis. 2008;14(4):641-3.

46. Alper G. Acute disseminated encephalomyelitis. J Child Neurol. 2012;27(11):1408-25.

47. Gwak H, Koh S, Lee K. Acute Disseminated Encephalomyelitis Following Pneumococcal Vaccination. J Korean Neurol Assoc. 2016;34(3):256-8.

48. Waldman AT, Gorman MP, Rensel MR, Austin TE, Hertz DP, Kuntz NL, et al. Management of pediatric central nervous system demyelinating disorders: Consensus of United States neurologists. J Child Neurol. 2011;26(6):675-82.

49. Pohl D, Tenembaum S. Treatment of acute disseminated encephalomyelitis. Curr Treat Options Neurol. 2012;14(3):264-75.

50. Williams T, Thorpe J. Post-infective transverse myelitis following Streptococcus pneumoniae meningitis with radiological features of acute disseminated encephalomyelitis: a case report. J Med Case Rep. 2012 Sep;6:313.

51. Jorens PG, Parizel PM, Demey HE, Smets K, Jadoul K, Verbeek MM, et al. Meningoencephalitis caused by Streptococcus pneumoniae: A diagnostic and therapeutic challenge. Diagnosis with diffusion-weighted MRI leading to treatment with corticosteroids. Neuroradiology. 2005;47(10):758-64.

\section{Table}


Table 1 - List and features of similar cases of ADEM following streptococcal meningitis reported in literature.

\begin{tabular}{|c|c|c|c|c|c|c|c|}
\hline & & Age/gender & $\begin{array}{l}\text { Time of } \\
\text { ADEM } \\
\text { diagnosis } \\
\text { after } \\
\text { meningitis }\end{array}$ & $\begin{array}{l}\text { Type and } \\
\text { location of } \\
\text { brain lesions }\end{array}$ & Therapy & Risk factors & Outcome \\
\hline \multirow[t]{5}{*}{ ADULT } & $\begin{array}{l}\text { Huhn, } \\
2014(19)\end{array}$ & $61 \mathrm{y}, \mathrm{F}$ & 2 days & $\begin{array}{l}\text { large bilateral } \\
\text { white matter } \\
\text { lesions }\end{array}$ & $\begin{array}{l}\text { 10-day pulse of } \\
\text { methylprednisolone }\end{array}$ & $\begin{array}{l}\text { splenectomy } \\
\text { without } \\
\text { pneumococcal } \\
\text { vaccination }\end{array}$ & $\begin{array}{l}\text { recovery, } \\
\text { no further } \\
\text { relapses }\end{array}$ \\
\hline & $\begin{array}{l}\text { Majzoobi, } \\
2014(12)\end{array}$ & $27 \mathrm{y}, \mathrm{M}$ & 10 days & $\begin{array}{l}\text { hyper-signal in } \\
\text { T2 images, } \\
\text { with } \\
\text { symmetric } \\
\text { patterns in } \\
\text { subcortical, } \\
\text { periventricular, } \\
\text { and pons } \\
\text { regions }\end{array}$ & $\begin{array}{l}\text { prednisolone e.v. } \\
\text { for } 10 \text { days, } \\
\text { followed by oral } \\
\text { tapering }\end{array}$ & - & $\begin{array}{l}\text { full } \\
\text { recovery } \\
\text { within a } \\
\text { three- } \\
\text { month } \\
\text { follow-up }\end{array}$ \\
\hline & $\begin{array}{l}\text { Ueda, } \\
2009(20)\end{array}$ & $58 \mathrm{y}, \mathrm{M}$ & 11 days & $\begin{array}{l}\text { tumor-like } \\
\text { hyperintensity } \\
\text { signal lesions } \\
\text { with ring } \\
\text { enhancements } \\
\text { in the right } \\
\text { frontal lobe }\end{array}$ & $\begin{array}{l}\text { corticosteroid pulse } \\
\text { therapy for } 6 \text { days }\end{array}$ & - & recovery \\
\hline & $\begin{array}{l}\text { Kureshiro, } \\
2008(22)\end{array}$ & 57 y, F & 13 days & $\begin{array}{l}\text { white matter } \\
\text { lesions on } \\
\text { frontal lobe } \\
\text { and temporal } \\
\text { lobe seen in } \\
\text { T2-weighted } \\
\text { images }\end{array}$ & $\begin{array}{l}\text { 3-day high-dose } \\
\text { methylprednisolone }\end{array}$ & - & recovery \\
\hline & $\begin{array}{l}\text { Ohnishi, } \\
2007(21)\end{array}$ & 39 y, M & 4 days & $\begin{array}{l}\text { high-intensity } \\
\text { lesions in the } \\
\text { white cerebral } \\
\text { matter }\end{array}$ & $\begin{array}{l}\text { 3-day high-dose } \\
\text { methylprednisolone }\end{array}$ & - & $\begin{array}{l}\text { visual } \\
\text { impairment }\end{array}$ \\
\hline \multirow[t]{2}{*}{ PEDIATRIC } & $\begin{array}{l}\text { Jorens, } \\
2008(23)\end{array}$ & $\begin{array}{l}7 \text { months, } \\
\text { F }\end{array}$ & 3 days & $\begin{array}{l}\text { multiple areas } \\
\text { of increased } \\
\text { signal } \\
\text { intensity } \\
\text { involving both } \\
\text { white and gray } \\
\text { matter }\end{array}$ & $\begin{array}{l}\text { pulse dose of } \\
\text { methylprednisolone } \\
\text { for three days }\end{array}$ & $\begin{array}{l}\text { no } \\
\text { pneumococcal } \\
\text { vaccination }\end{array}$ & $\begin{array}{l}\text { brain } \\
\text { atrophy, } \\
\text { hearing } \\
\text { loss, } \\
\text { epilepsy, } \\
\text { hypotonus }\end{array}$ \\
\hline & $\begin{array}{l}\text { Yu, } 2013 \\
(24)\end{array}$ & $4 y, F$ & 8 days & $\begin{array}{l}\text { multifocal } \\
\text { changes } \\
\text { mainly in } \\
\text { white matter } \\
\text { (top of } \\
\text { bilateral } \\
\text { cerebral } \\
\text { ventricles and } \\
\text { centrum } \\
\text { semiovale), } \\
\text { with } \\
\text { bithalamic } \\
\text { involvement }\end{array}$ & $\begin{array}{l}\text { high-dose } \\
\text { intravenous } \\
\text { methylprednisolone } \\
(20 \mathrm{mg} / \mathrm{kg} \text { for } 5 \\
\text { days) and } \\
2 \mathrm{~g} / \mathrm{kg} \text { IVIG }\end{array}$ & $\begin{array}{l}\text { no } \\
\text { pneumococcal } \\
\text { vaccination }\end{array}$ & $\begin{array}{l}\text { recovery, } \\
\text { no further } \\
\text { relapses } \\
\text { after } 3 \text { y } \\
\text { follow-up }\end{array}$ \\
\hline
\end{tabular}

Another case report has been cited in the paper by Kureshiro et al.(22), but no abstract is available (Kikuchi K, Takahashi S, Uematsu Dai et al .: A case of acute disseminated encephalomyelitis caused by pneumococcal meningitis. Saitama Medical Association Journal 1999; 33: 886-889). 


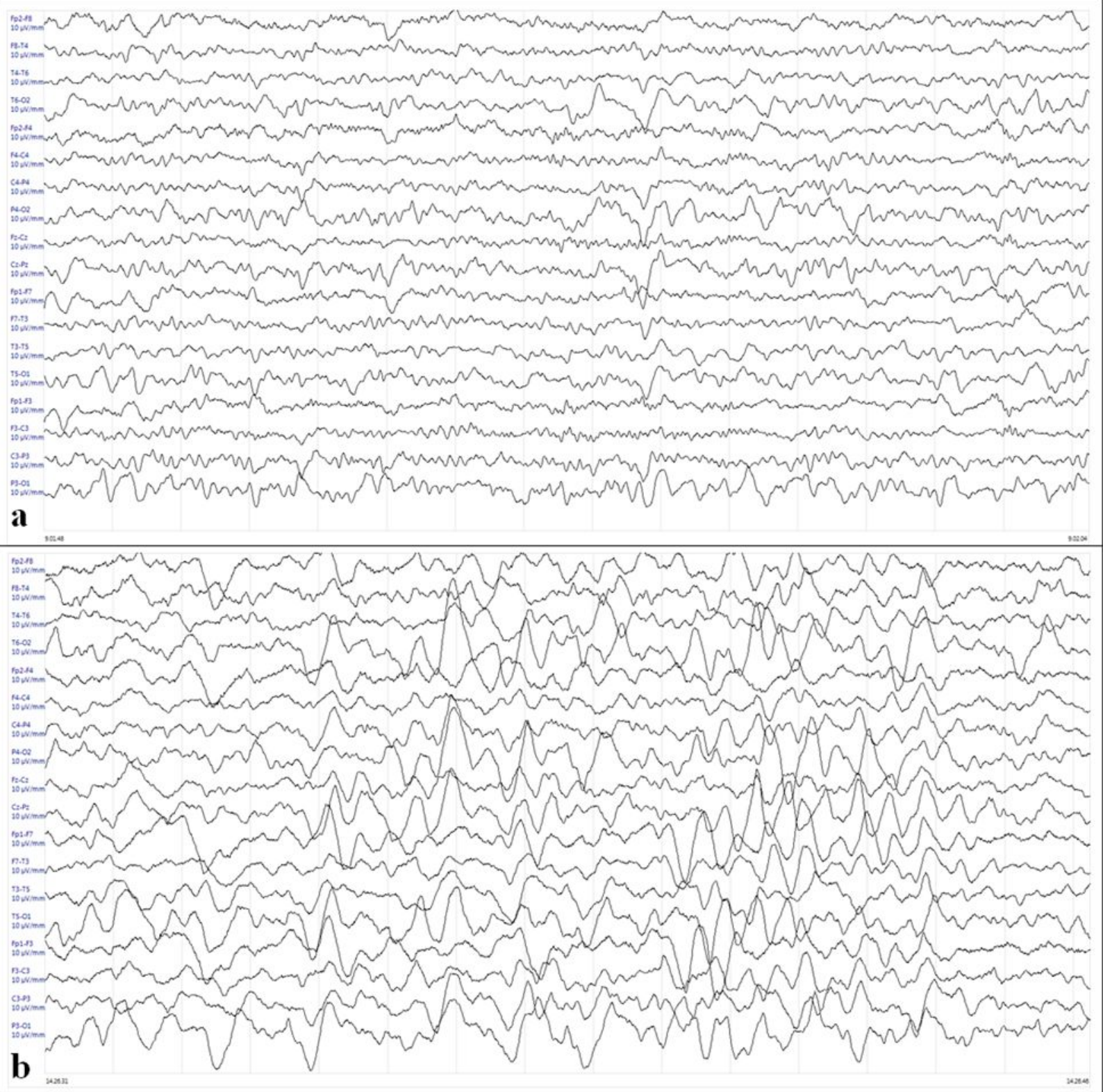

\section{Figure 1}

EEG traces recorded during day 1 and day 3 after admission [a] EEG performed at admission (diagnosis of pneumococcal meningitis), showing slowing of the background activity, particularly in the posterior regions. [b] EEG performed on the third day after admission (worsening of neurological conditions leading to the diagnosis of ADEM): slow background activity, with highamplitude diffuse monomorphic delta waves (1-2 Hz). 


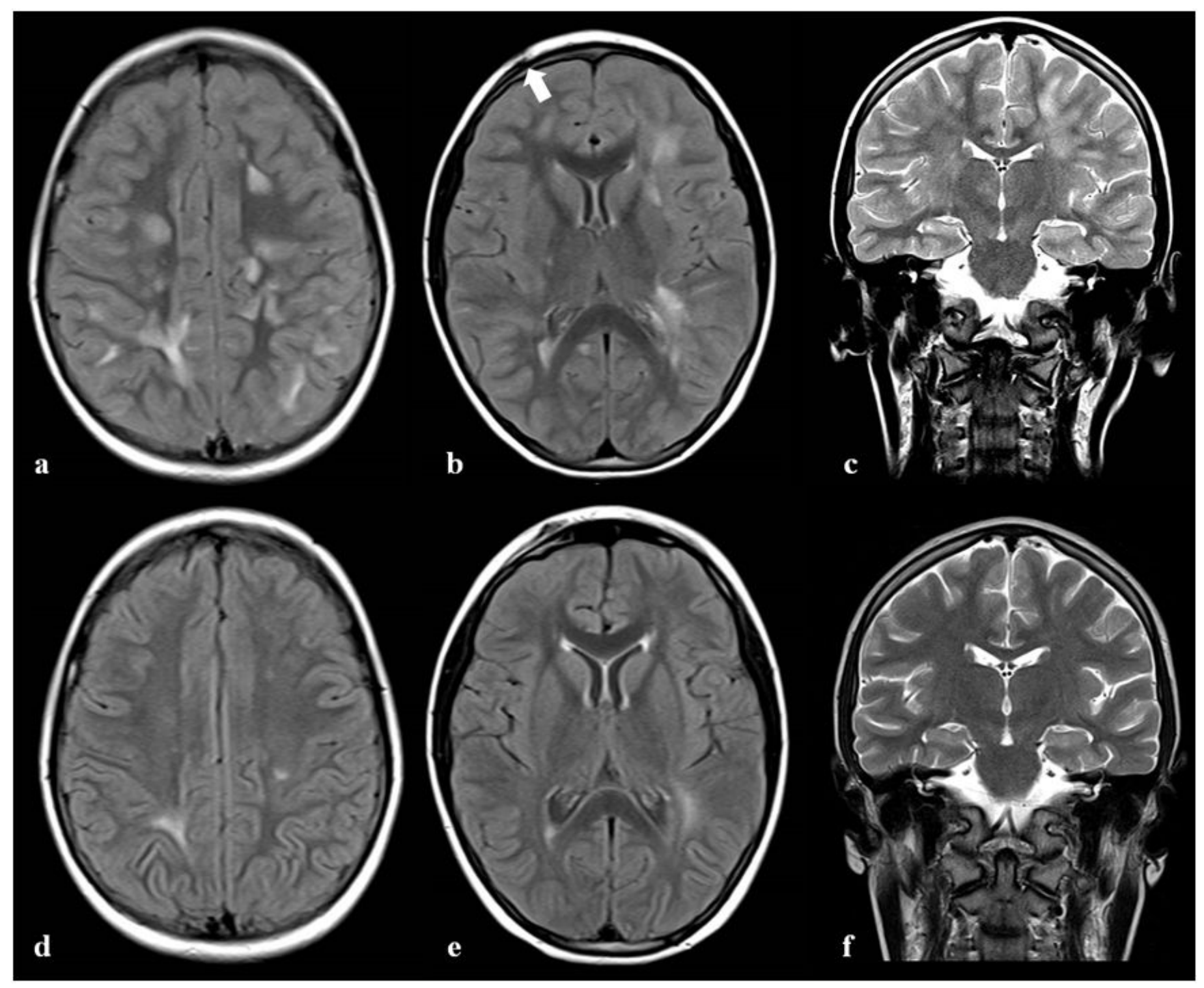

Figure 2

Pre and post-treatment brain MRI in our 10-year-old patient. [a,b,c] Brain MRI performed on day 3 after admission, when neurological conditions of the patient worsened in spite of decreasing of inflammatory parameters and progressive normalization of CSF analysis. Multiple T2-hyperintense bilateral lesions in the supratentorial white matter, with moderate diffusion restriction in the left frontal subcortical area and in the right peritrigonal area, leading to the diagnosis of ADEM. Evidence of bone breach in the posterior wall of the right frontal sinus (white arrow in b). [c,d,e] Brain MRI performed on day 17 after admission, at the end of high-dose steroid therapy. Marked reduction in number and size of the previously described white matter lesions, with persistence of small lesions in the periventricular areas and of point signal alteration in the fronto-parietal subcortical areas. 


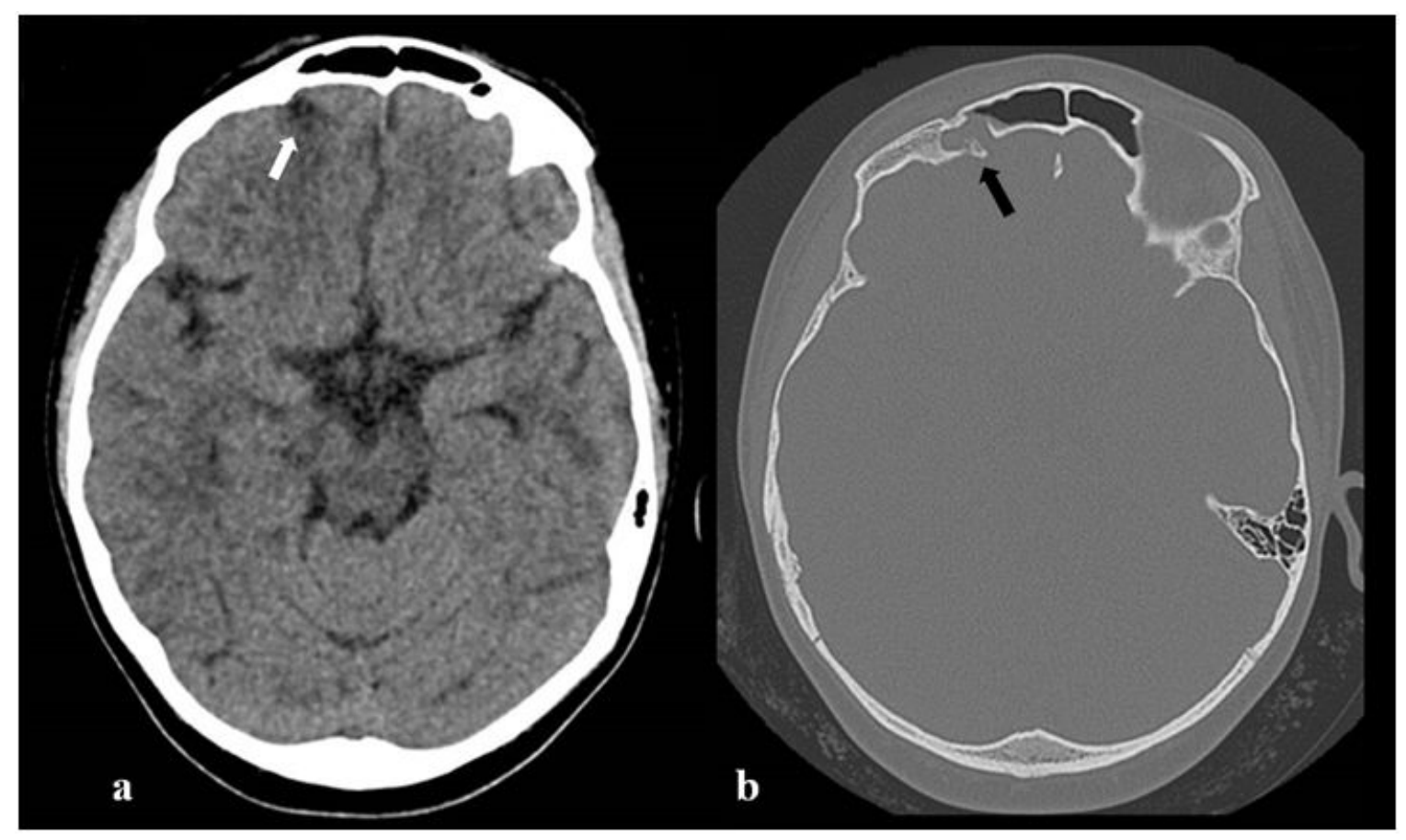

\section{Figure 3}

CT scan performed on day 17, aimed at better characterize the bone lesion discovered in the right frontal sinus. Right corticosubcortical hypodense area in the frontal lobe, compatible with a gliotic-malacic lesion, result of a previous parenchymal posttraumatic insult (white arrow in a). Bone gap $(12 \times 5 \times 4 \mathrm{~mm})$ with sclerotic margins just adjacent to the lateral wall of the right frontal sinus and little bone breach in the roof of the right orbit (black arrow in b). These findings are compatible with a previous bone blown-in traumatism and consequent parenchymal lesion.

\section{Supplementary Files}

This is a list of supplementary files associated with this preprint. Click to download.

- CAREchecklist.pdf 